\title{
Targeting ideal oral vaccine vectors based on probiotics: a systematical view
}

\author{
Boyu Jiang ${ }^{1,2} \cdot$ Zhendong $\mathrm{Li}^{1,2} \cdot$ Bingming $\mathrm{Ou}^{1,2,3} \cdot$ Qiangde Duan ${ }^{1,2} \cdot$ Guoqiang $\mathrm{Zhu}^{1,2}$
}

Received: 16 January 2019 / Revised: 11 March 2019 / Accepted: 12 March 2019 / Published online: 26 March 2019

(C) Springer-Verlag GmbH Germany, part of Springer Nature 2019

\begin{abstract}
Probiotics have great potential to be engineered into oral vaccine delivery systems, which can facilitate elicitation of mucosal immunity without latent risks of pathogenicity. Combined with the progressive understanding of probiotics and the mucosal immune system as well as the advanced biotechniques of genetic engineering, the development of promising oral vaccine vectors based on probiotics is available while complicated and demanding. Therefore, a systematical view on the design of practical probiotic vectors is necessary, which will help to logically analyze and resolve the problems that might be neglected during our exploration. Here, we attempt to systematically summarize several fundamental issues vital to the effectiveness of the vector of probiotics, including the stability of the engineered vectors, the optimization of antigen expression, the improvement of colonization, and the enhancement of immunoreactivity. We also compared the existent strategies and some developing ones, attempting to figure out an optimal strategy that might deserve to be referred in the future development of oral vaccine vectors based on probiotics.
\end{abstract}

Keywords Probiotics $\cdot$ Oral vaccine vector $\cdot$ Stability $\cdot$ Colonization $\cdot$ Immunoreactivity

\section{Introduction}

From the discovery of probiotics to nowadays that probiotics have been officially defined as living bacteria that, when administered in adequate amounts, confer a health benefit on the host (Córdoba Park Hotel 2001), various studies on probiotics have contributed to a clearer and more specific understanding of probiotics. For example, these studies about direct or indirect

Boyu Jiang, Zhendong Li and Bingming Ou contributed equally to this work.

\footnotetext{
Qiangde Duan

dqd8358@163.com

$\triangle$ Guoqiang Zhu

yzgqzhu@yzu.edu.cn

1 College of Veterinary Medicine, Yangzhou University, Yangzhou 225009, China

2 Jiangsu Co-Innovation Center for Important Animal Infectious Diseases and Zoonoses, Joint International Research Laboratory of Agriculture and Agri-Product Safety of Ministry of Education of China, Yangzhou 225009, China

3 College of Life Science, Zhaoqing University, Zhaoqing 526061, China
}

interactions between probiotics and the host have demonstrated that, except for nutrient effects, probiotics may also play a positive role in the treatment of many health issues such as allergy (Amar et al. 2011), diabetes (Floch et al. 2011), or even depression (Pinto-Sanchez et al. 2017). Several of them have a promising prospect of improving human health in two dimensions, namely the extended range of illness can be treated and the enhanced effectiveness in treating one specific illness.

Although theoretic studies of probiotics have achieved great success, its true value relies more on practical application. Currently, most studied probiotics are Lactobacillus (Seegers 2002), Bifidobacterium (Grimm et al. 2014), some nonpathogenic strains of Escherichia coli (E. coli) such as the well-known E. coli Nissle $1917(\mathrm{EcN})$ strain (Wassenaar 2016; Ou et al. 2016) and the somewhat lesser known Streptococcus strains like Streptococcus thermophilus (Caggianiello et al. 2016). Their commercial products have already appeared on the market such as Cuturelle, produced by I-health (the USA, a company founded in 2011) and Mutaflor, produced by Ardeypharm GmbH (Germany, a pharmaceutical company founded in 1970). Originally, those products are mainly aimed at maintaining gastrointestinal stability, protecting people and animals, especially domestic animals, from diarrhea, enterogastritis, or other gastrointestinal 
diseases. Afterwards, researchers have concluded that the role of probiotics does not exclusively involve in gastrointestinal health. There have been many studies which aim to use probiotics as a valuable alternative of antibiotics to solve increasingly severe problems of antibiotic resistance (Floch et al. 2011; Gomez et al. 2016; Hossain et al. 2017). Then, as the rise of omics especially of the genomics, proteomics, and metabolomics, the complex and profound mechanisms behind probiotics and the potential application based on them have kept being unveiled.

On the other hand, practical and valid utilization of probiotics is still limited for some of their disadvantages (Table 1). It is worthwhile making the most of probiotics, especially engineering them for specific purposes, since strategies of gene engineering or synthetic biology are controllable and predictable. Existing exploration of such strategies includes using engineered probiotics as the biofactory of producing therapeutic proteins or cytokines in vivo, using them as mechanical vectors of drugs or using them as vectors of vaccines (Kumar et al. 2016). Among these applications, using probiotics as live vehicles of oral vaccines is of great value though some problems remained to be solved. In this review, we systematically described several key points that deserve our attention, including the stability of antigen expression, the optimization of antigen production, the successful colonization of probiotic vehicles and the improved efficiency of immune activation (Fig. 2), and some of which might be previously ignored when developing an effective oral vaccine based on probiotics. We also focus on the existent and innovative solutions to them.

\section{Why choose probiotics as oral vaccines vectors?}

Compared with parenteral vaccination which induces systemic immunity, oral vaccination excels in inducing mucosal immunity. Since systemic immunity cannot efficiently extend to mucosal surfaces of the intestinal mucous membrane (RussellJones 2000), which is the frontier against the invasion of pathogens in the gut, it is reasonable to develop effective oral vaccines to protect humans and animals from enteric infection. What is more, oral vaccines are also economically advantageous, as their storage and transportation are not as demanding as traditional vaccines, especially the live vaccine which strictly requires low temperature before inoculation. Except fewer demands for expensive equipment, a smaller number of professional doctors or nurses are needed when extensive oral vaccination is carried out.

However, traditional vaccine delivery vehicles, which are based on attenuated pathogens like Salmonella typhimurium, Shigella sonnei, Bacillus anthracis (B. anthracis), and Mycobacterium bovis have several disadvantages, including the failure to induce high protective levels of immunity and the risk that attenuated bacteria may convert back to virulent status (Holmgren and Czerkinsky 2005; Medina and Guzman 2001). There are two main reasons behind the failure of effective immune protection. Firstly, traditional oral vaccines are not able to reach the membrane surface efficiently because they are not specifically targeted to the essential mucosal immune structure like mesenteric lymph nodes and Peyer's patches, where mucosal immunity is mainly induced (Owen et al. 2013). Furthermore, they are less likely to survive through the harsh low-acid environment in the stomach, and also prone to be physically eliminated and enzymatically digested in the extremely complicated condition of the gut. Although the virulence of pathogen-based delivery vehicles is attenuated, they still possess strong immunogenicity, which would also induce the unnecessary immune response to eradicate them before recognition of antigen and thus weakening the effect of vaccines.

In terms of these aspects, the proposal of using probiotics as delivery vectors of vaccine seems to be a promising solution to the undesirable immune efficacy of traditional oral vaccines. Firstly, they have been proven to colonize on the mucosal surface of the intestinal tract, respiratory tract, and genital tract (Dodoo et al. 2017), without stimulating strong immunoreaction. And some species of probiotics could help transport antigens through Peyer's patches (Isolauri et al. 1993). Furthermore, investigators also demonstrated that probiotics can exert some

Table 1 Advantages and disadvantages of probiotic vaccine vectors

\begin{tabular}{ll}
\hline Advantages & Disadvantage \\
\hline $\begin{array}{l}\text { 1. Safety of probiotics (Córdoba Park Hotel 2001); } \\
\text { 2. Economical and convenient oral immunization route; }\end{array}$ & $\begin{array}{l}\text { 1. Possibility of oral tolerance (Rombout et al. 2011); } \\
\text { 3. Enhancement of vaccine efficacy (Fang et al. 2000; }\end{array}$ \\
$\begin{array}{l}\text { Taylor et al. 2006); } \\
\text { 4. Relatively more stable colonization and survival in vivo, } \\
\text { especially the harsh gut environment (Bezkorovainy 2001); }\end{array}$ & 3. Innate low immunogenicity of probiotics; \\
$\begin{array}{l}\text { 5. Additional beneficial functions, including anti-inflammation } \\
\text { (Kuda et al. 2014) and antibacterial activity (Czaplewski et al. 2016) etc. }\end{array}$ & $\begin{array}{l}\text { 4. Poor understanding of basic mechanisms behind } \\
\text { probiotics compared with some pathogens. }\end{array}$ \\
\hline
\end{tabular}


positive functions of immunomodulation (Rajput and Li 2012) such as enhancement of secreted IgA (SIgA) secretion and homeostasis of the immune system (Herich and Levkut 2002), which further contribute to the effectiveness of vaccination. In a word, probiotics own some beauties that deserve to be explored to develop effective oral vaccines.

So far, there have been many attempts on the development of oral vaccine delivery vehicles (Table 2). And among them, Lactobacillus, Bifidobacterium, and nonpathogenic E. coli strains have been studied often. As early as 1990, the lactic acid bacteria (LAB) - Streptococcus lactis IL1403 was firstly developed into a vaccine vector. The cell was engineered to produce PAc protein (antigen I/II) anchored on the surface and then killed by formalin (Iwaki et al. 1990). After intragastric immunization, specific $\operatorname{IgG}$ and $\operatorname{IgA}$ antibodies against PAc protein were detected. Then, researchers turned to live probiotic vaccines and tested the immune effectiveness of many members of the LAB group expressing immunogenic tetanus toxin C-terminal fragment (TTFC) (Wyszynska et al. 2015). Except the well-studied LAB, the EcN also has a great potential as vectors of pathogenic components. For instance, recombinant $\mathrm{EcN}$ which expressed fimbrial adhesin $\mathrm{K} 88$ has been developed to induce protective mucosal immunity against enterotoxigenic E. coli (ETEC) (Remer et al. 2009). On the other hand, while probiotics possess attractive characteristics mentioned above, they are not a guarantee of perfect vaccine vectors due to the existent problems involved in stability, expression level of recombinant protein, colonization, and specificity of vaccines remains unsolved. Except the attempt to tackle the problems to remain solved, some innovative strategies also deserve our attention.

\section{Genetic stability}

Although the rapid progress of genetic techniques has allowed investigators to genetically manipulate probiotics to improve, introduce, or knockout some of their phenotypes, the stability of modulated strains is still the foundation for the advanced development of recombinant oral vaccines (Ou et al. 2016). Genetic modulation usually involves in introducing exogenous genes encoding target antigen protein or just as DNA antigen (Gahan et al. 2007), into suitable recipients, and their subsequent replication and expression. In order to achieve this goal, plasmid-based overexpression, a very convenient method while with some disadvantages, has been widely performed. Taking the EcN strain as an instance, studies on the EcN have found the existence of two small cryptic plasmids termed pMUT1 and pMUT2 which are genetically stable and unable to transfer to other strains of $E$. coli (Sonnenborn and Schulze 2009). Based on that, Remer et al. (2009) explored the method of expressing the K88 fimbrial adhesin from the ETEC on the EcN. They attempted to insert the corresponding

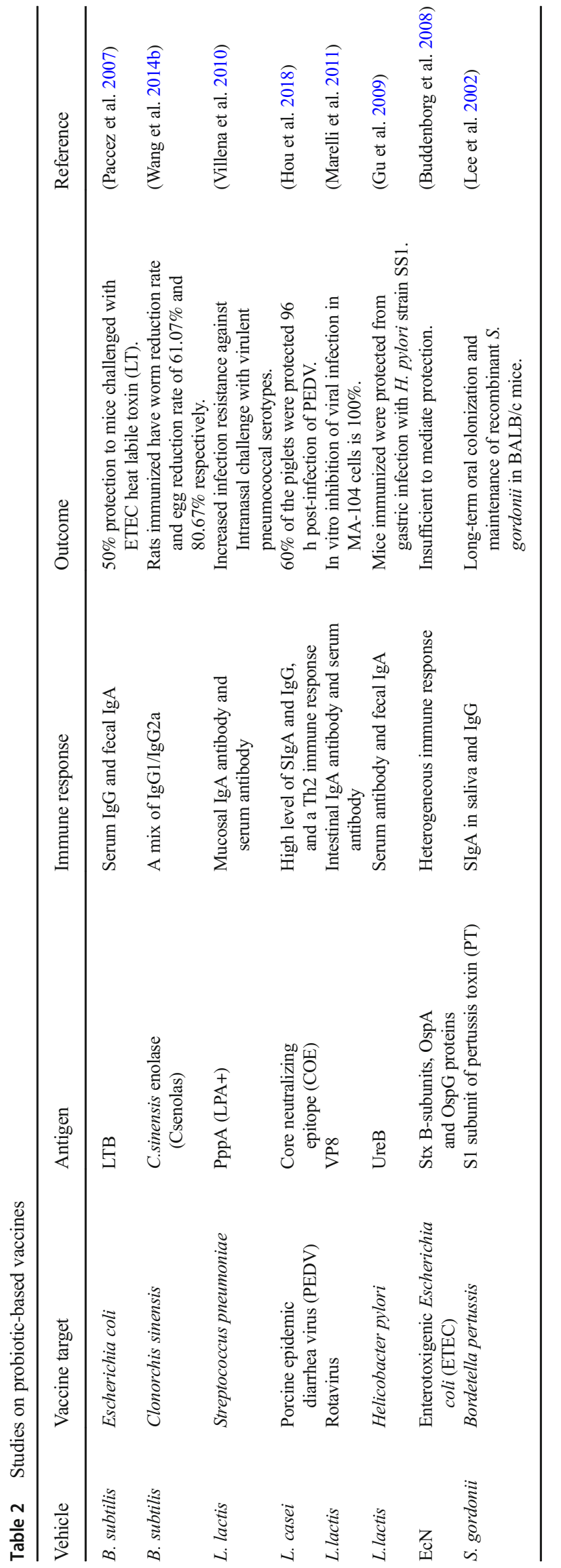


gene into pMUT2 and then orally administrated the recombinant strain into mice. Meanwhile, Buddenborg et al. (2008) have also developed a tripartite vector system which used the adhesin involved in diffuse adherence (AIDA) system to express heterologous antigens on the surface of EcN. The stability of this system has been evaluated through subculture on agar plates and the result showed that neither pMUT1 nor pMUT2 could contribute to the stability of the segregational plasmid, which indicated that although pMUT1 and pMUT2 are stable plasmids, their ability to facilitate stable heterologous gene expression remains invalid. In addition to the EcN, studies on pSIP expression vectors in Lactobacillus plantarum demonstrated that the pSIP expression system is applicable to intracellular expression, secretion, and surface anchoring of heterologous proteins (Anbazhagan et al. 2013; Bohmer et al. 2012; Fredriksen et al. 2012). However, when it was applied to other Lactobacillus strains to produce NucA (model protein), unstable transformants were observed and one possible explanation for that is due to the expression of NucA that may lead strains highly burdensome (Karlskas et al. 2014), a widely shared potential downside of the plasmid-based overexpression strategy.

To overcome the problem of instability, besides the attempt to search for more suitable plasmid vectors, it is a promising alternative to directly integrate heterologous genes into the bacterial chromosome because chromosomal integration can not only make contributions to the stable expression of inserted genes but also reduce the metabolic burden caused by plasmid-replication (Ou et al. 2018). However, although chromosomal integration takes advantages in stable expression of genes, it still needs improvements in the mono-copy expression level of genes and the convenience of operation when compared with plasmid-based overexpression. Methods of increasing the expression level will be discussed in the next section and here we focus on several representative strategies that can facilitate either random chromosomal integration or site-specific integration.

The phage Mu-driven transposition system which can randomly insert the Mu DNA into the bacterial chromosome has been widely applied to in vitro DNA transposition (Akhverdyan et al. 2011). Its function depends on the formation of transposome, a complex of Mu coding transposase, $\mathrm{MuA}$, and DNA in the cell. Once formed, it can induce DNA cleavage and DNA strand transformation (GoldhaberGordon et al. 2002). Original Mu transposition used to require a range of protein and include several steps (Chaconas et al. 1985), but nowadays, some improved systems make it both effective and convenient. For instance, a three-step system consisting of Mu transposon and FLP/FRT system can achieve gene insertions through mini-Mu-based repetitive transposition and the FLP/FRT-based cycles of selection marker excision (Wei et al. 2010). However, its stability and efficiency are DNA length-limited (Wei et al. 2010).
In terms of site-specific recombination of chromosomes, tools of homologous recombination are available and among them, the $\lambda$ Red system is one of the most practical and widely utilized methods. It contains three essential proteins including Exo, Beta, and Gam from I-bacteriophage which can apply double-stranded DNA (dsDNA) or single-stranded DNA (ssDNA) into a specific chromosomal target (Warming et al. 2005). Furthermore, when combined with site-specific recombinase (SSR) systems including Cre/loxP and Flp/ FRT, $\lambda$ Red system can manipulate almost any genetic alteration and achieve drug resistance marker-free gene deletion in just one step (Murphy 2016). Compared with dsDNA-based recombination which only has only $0.01 \%$ surviving through transformation, the ssDNA-based one can be as high as $25 \%$ (Wang and Church 2011). And through hybridizing to the exposed lagging strand at the replication fork, it can integrate ssDNA into the genome with the most efficiency (Wu et al. 2005). Based these advantages, a multiplex genome-editing tool named multiplex automated genome engineering (MAGE) has been developed to perform several chromosomal changes simultaneously which facilitates the chromosome modification (Wang et al. 2009). But this method is also limited to the length of gene insertions (Wang and Church 2011).

Until now, the cutting-edge technique CRISPR-Cas system seems to own the most efficiency, simplicity, and precision (Kanchiswamy et al. 2016). CRISPRs consist of an array of a 30-40 bp short, direct repeat sequence that can be transcribed into two essential RNA, including the transactivating crRNA (tracrRNA) and the precursor crRNA (precrRNA) (Cong et al. 2013). The guide RNA (gRNA), a fusion of tracrRNA and mature crRNA, can specifically target to a DNA sequence and guide the RNA-guided DNA endonuclease Cas9 to cleave the gene target (Cong et al. 2013). Unlike the aforementioned systems, CRISPR-Cas is highly compatible that can be applied to almost all cells including various probiotics bacterial strains (Bonacina et al. 2017; Stout et al. 2017; Van Pijkeren and Barrangou 2017). What is more, its components can also complement other systems to make a more powerful tool (Jiang et al. 2015), and this strategy merits further exploration.

\section{Optimize antigen production}

On the foundation of stable genetic engineering, one of the ensuing concerns is the optimization of heterologous gene expression since the effectiveness of immune response of oral vaccine is influenced significantly by the way of expression and amount of the expressed antigens (Ding et al. 2018) (Table 3). Currently, target antigens are usually displayed in three forms - cytoplasmic, anchored on cell surface, or secreted (Fig. 1), and here, we focus the latter two forms which are performed more frequently. In the surface display system, 
Table 3 Some strategies of optimizing antigen production

\begin{tabular}{|c|c|c|c|}
\hline Type & Strategies & Content & Reference \\
\hline \multirow[t]{3}{*}{ Selection of expression systems } & Cytoplasmic expression system & Listeriolysin $\mathrm{O}$ & (Radford et al. 2002) \\
\hline & Cell surface anchoring system & $\begin{array}{l}\text { The key point is to select suitable anchoring } \\
\text { motif including FimH, TolC, and } \\
\text { Lpp-OmpA (E. coli); S-layer proteins } \\
\text { (Lactococcus lactis); FliC (Salmonella); } \\
\text { LPXTG anchoring motif }\left(\mathrm{G}^{+}\right) \text {. }\end{array}$ & $\begin{array}{l}\text { (Vogt et al. 2016) } \\
\text { (Siegel et al. 2016) }\end{array}$ \\
\hline & Secretion system & $\begin{array}{l}\text { Type I, type III, type VI, and type VII } \\
\text { secretion system, E. coli alpha-hemolysin } \\
\text { secretion system }\left(\mathrm{G}^{-}\right) \\
\text {ESAT-6 secretion system }\left(\mathrm{G}^{+}\right)\end{array}$ & $\begin{array}{l}\text { (da Silva et al. 2014; } \\
\text { Gentschev et al. 2002; } \\
\text { Schneewind and Missiakas 2012) }\end{array}$ \\
\hline \multirow[t]{3}{*}{ Enhancement of gene expression } & Selection of recombination loci & OriC & (Bryant et al. 2014) \\
\hline & Promoters & $\begin{array}{l}\text { ParaB, PrhaB, PrhaS, Ptac, } \\
\text { Psyn1, and Psyn } 4\end{array}$ & $\begin{array}{l}\text { (Chaves et al. 2002; } \\
\text { Haldimann and Wanner 2001; } \\
\text { Wang et al. 2014a) }\end{array}$ \\
\hline & Enhancers & CRISPR-Cas9 tailored strains & (Ou et al. 2018) \\
\hline Fusion-strategy & $\begin{array}{l}\text { Fusion antigen with nature } \\
\text { or synthesized peptides }\end{array}$ & $\begin{array}{l}\text { Usp45 signal peptide (SPUsp) and } \\
\text { synthetic propeptide LEISS }\end{array}$ & (Ribeiro et al. 2002) \\
\hline
\end{tabular}

$G^{+}$, Gram positive; $G^{-}$, Gram negative

it mainly involves in fusing target protein to surface protein, and therefore the selection of anchoring motif is of great significance. Surface proteins include FimH, TolC, and Lpp-OmpA of E. coli; S-layer proteins of Lactococcus lactis (L. lactis) and FliC of Salmonella have been reported to facilitate expression of exogenous antigens (Vogt et al. 2016). What is more, in Gram-negative bacteria, a system of outer membrane vesicles has also been developed and such vesicles can incorporate the antigens and direct them to antigenpresenting cells (APCs) (da Silva et al. 2014). While in Gram-positive bacteria, the LPXTG anchoring motif has the potential to represent antigens (Siegel et al. 2016). When it comes to the secreted antigen, which has been reported to greatly contribute to the effectiveness of vaccines aimed at intracellular pathogens (Kaufmann and Hess 1999), widely utilized strategies are type I and type III secretion systems, both of which are applicable in Gram-negative bacteria including Salmonella, Yersinia, Shigella sp., and E. coli (da Silva et al.2014). Furthermore, a recently reported ESAT6 secretion, referred as type VII secretion system, also has the potential to be applied to Gram-positive bacteria, despite its less clear molecular mechanisms (Schneewind and Missiakas 2012). However, it is not easy to draw a conclusion that which strategy is the best since the efficiency of different methods is strain-dependent. For example, immune efficiency of antigen anchored on the surface of $L$. lactis is better than the two other forms because the production of anchored antigen is more than others (Ribeiro et al. 2002; Vitini et al. 2000). But it does not mean that the surface-anchored strategy is suitable to all other members of LAB.

Except for selecting suitable expression systems, there are other rewarding approaches to enhancing the expression of heterologous genes to optimize production of antigens. Compared with the mentioned plasmid-based overexpression, which involves in manipulating target genes into high-copy number plasmids, methods of improving bacterial chromosomal expression are increasing for getting more improvement. Firstly, the locus of the genome influences not only in the copy number but also in the level of transcription of genes (Ou et al. 2018). As demonstrated by Bryant et al. (2014), the different loci of the chromosome in E. coli $\mathrm{K}-12$ showed a maximal variance of 300-fold of the expression level, and the highest expression site and the lowest expression site are oriC and tam respectively. Other methods of enhancing expression cassette include employment of stronger promoters, enhancers, and ribosome-binding sites (RBSs). Promoters mainly comprise two types - inducible promoters and constitutive promoters, and studies on E. coli, Bifidobacterium sp., and LAB have shown the significance and efficiency of utilizing promoters, especially the constitutive promoter including ParaB, PrhaB, PrhaS, Ptac, Psyn1, and Psyn 4 in gene expression (Chaves et al. 2002; Haldimann and Wanner 2001; Wang et al. 2014a). Enhancers have been reported involving in the increased rate of gene expression in CRISPR-Cas9 tailored strains and RBSs is available to be designed and predicted through the computer (Ou et al. 2018). Moreover, the fusion strategy described above can be further explored. As reported by Ribeiro et al. (2002), when fusing the Usp45 signal peptide $\left(\mathrm{SP}_{\mathrm{Usp}}\right)$ with Brucella abortus antigen, L7/L12 and the result demonstrated that production of the protein L7/L12 increased sixfold. In addition to taking advantage of natural peptide, the same promotion effect has also been observed on the synthetic propeptide LEISS, which increased the secretion of heterologous protein in the L. lactis nearly tenfold (Nouaille et al. 2005). 
Target Antigen

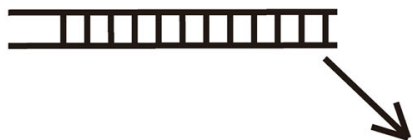

$\mathrm{M}$ cell or DC targeting peptide

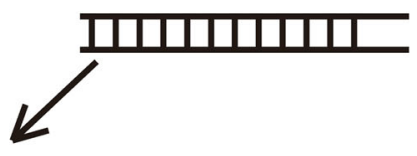

Plasmid

Target Antigen
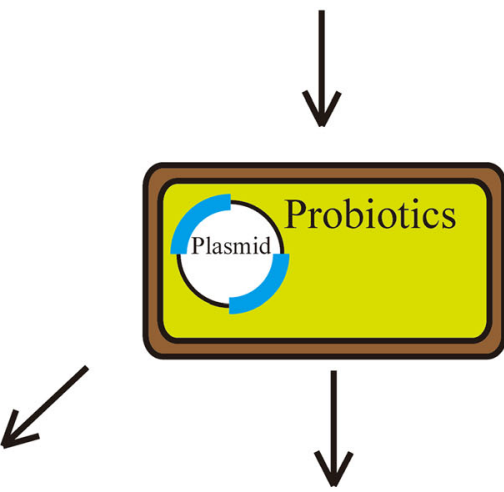

Anchored

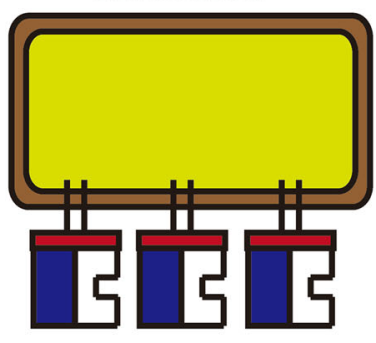

$\sqrt{ }$

Target Receptor

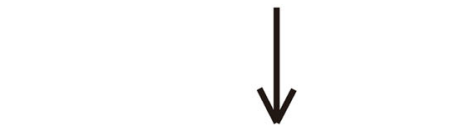

Secreted

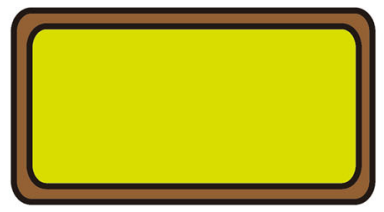

5
$\mathrm{M}$ cell or DC

targeting peptide

Anchoring motif

I5

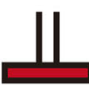

$\sqrt{ }$

Faciliting the recognization of $\mathrm{Ag}$
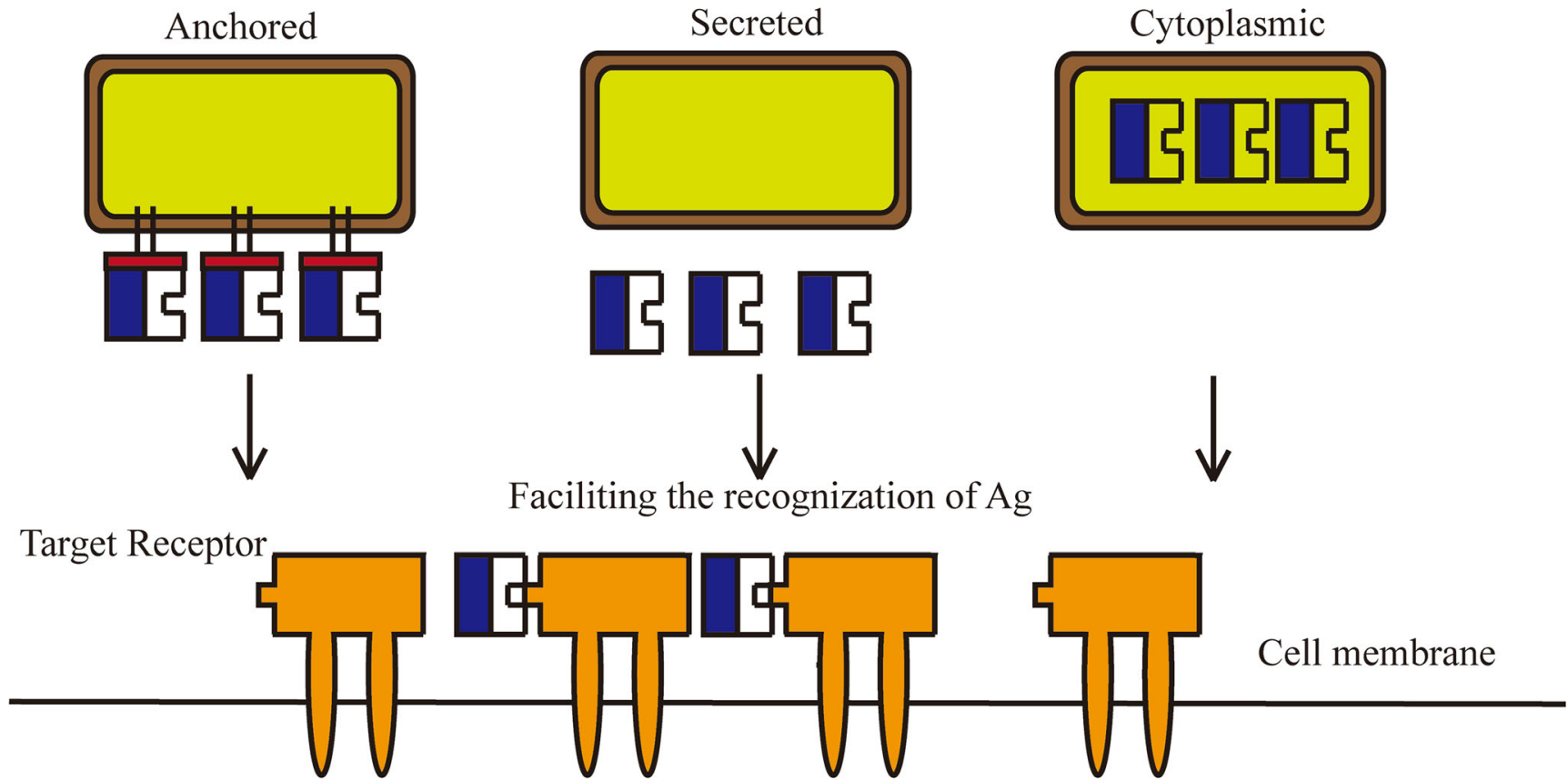

\section{$\mathrm{M}$ cell or $\mathrm{DC}$}

Fig. 1 Strategies of antigen expression and enhancement of immunoreactivity

There are three main forms of expressed antigens, including the one anchored on the surface of bacteria with the help of the anchoring

\section{Improve host colonization}

Provided that oral vaccine vectors are able to express target antigen with both stability and efficiency, effective immune priming reaction still requires necessary time, namely, probiotics need to persist in the gut for some time instead of motif, the one secreted outside, and the one produced in the cytoplasm. To enhance the specificity of antigen, namely, targeting it to the important $\mathrm{M}$ cells or DCs, an M cell or DC-targeting peptide has been fused with antigen which facilitates the recognition of antigen by M cells or DCs.

transiently existing. As orally administrated, the vaccine vector has to firstly undergo the extremely hard condition of low $\mathrm{pH}$ environment from stomach and intestinal tract. Studies on Lactobacillus and Bifidobacterium have shown a pretty low rate of survival after treated with acid at the level of gastric juices (Collado and Sanz 2007; Wang et al. 2018). Therefore, 


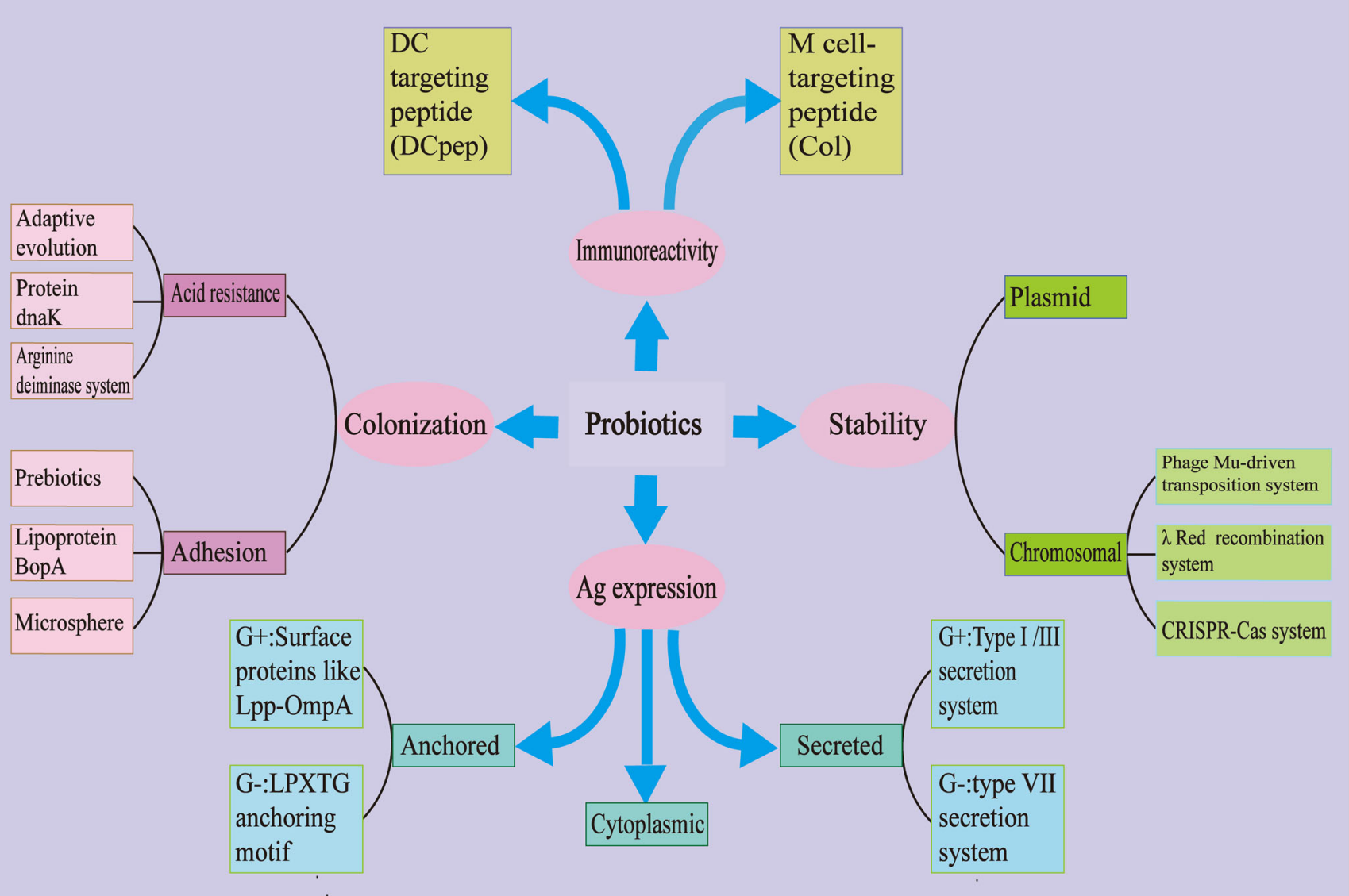

Fig. 2 Elements for a good vaccine vehicle based on probiotics To develop a good oral vaccine vector based on probiotics, firstly, a suitable probiotic strain needs to be selected carefully. And then the antigen gene has to be expressed stably, which depends on the technique of genetic engineering used. On the foundation of stability,

the improvement of oral vaccine vectors' acid resistance is of great significance. Until now, based on the advance of genomics, functional genomics, and high-throughput technologies, various mechanisms related to the acid resistance of bacteria have been investigated, including the arginine dihydrolase system (ADS) and malolactic fermentation which belong to neutralization processes, formation of biofilm and increased cell density, depletion of intracellular proton through F1-F0ATPase activation, amino acid decarboxylation, and protection and repair of cellular macromolecules, like DNA (Kanjee and Houry 2013; Wang et al. 2018). On the basis of these mechanisms, several strategies have been explored to enhance the survival of probiotics through extreme acid environment. Firstly, adaptive evolution and pre-adaptation are convenient tools to improve acid resistance of strains like Lactobacillus casei, and that usually related to treating bacteria with sublethal level of acid or other stress for a period of time (Zhang et al. 2012). Compared with the unstable and time-consuming adaptive strategy, engineering specific factors that affect acid resistance are promising. In the example of L. lactis, Abdullah the form of expression should be considered simultaneously, the M cell or DC-targeting peptide can be fused with expressed antigen to enhance its immunoreactivity. Finally, the survival of vectors should be improved in terms of acid resistance and adherence.

$\mathrm{Al}$ et al. (2010) have transferred protein DnaK of E. coli into L. lactis NZ9000 and found that engineered L. lactis NZ9000 showed higher tolerance to lactic acid. Alternative approaches include engineering amino acid metabolism like the arginine deiminase (ADI) system (Wu et al. 2012), introducing exogenous biosynthetic systems like the trehalose de novo biosynthetic pathway of Propionibacterium freudenreichii (Carvalho et al. 2011) or the addition of nutrients with protective functions such as aspartate (Wu et al. 2012), but deeper mechanisms behind them remain to be elucidated.

After survival through detrimental gastric acid, adhesion and colonization of vectors to the surface of intestinal tract is the important issue to be considered (Fig. 3). Although probiotics' ability to inhibit adherence of pathogens was well reported (Collado et al. 2007b; Kanmani et al. 2013), in oral vaccine vectors, their adherence to the mucosal surface still needs improvement. Lin et al. (2006) assayed five commercial $\mathrm{LAB}$ products, referred as $\mathrm{A}, \mathrm{B}, \mathrm{C}, \mathrm{D}$, and $\mathrm{E}$, for their adherence to human intestinal epithelium, and the results demonstrated that among the 25 isolates of the five products, only the 


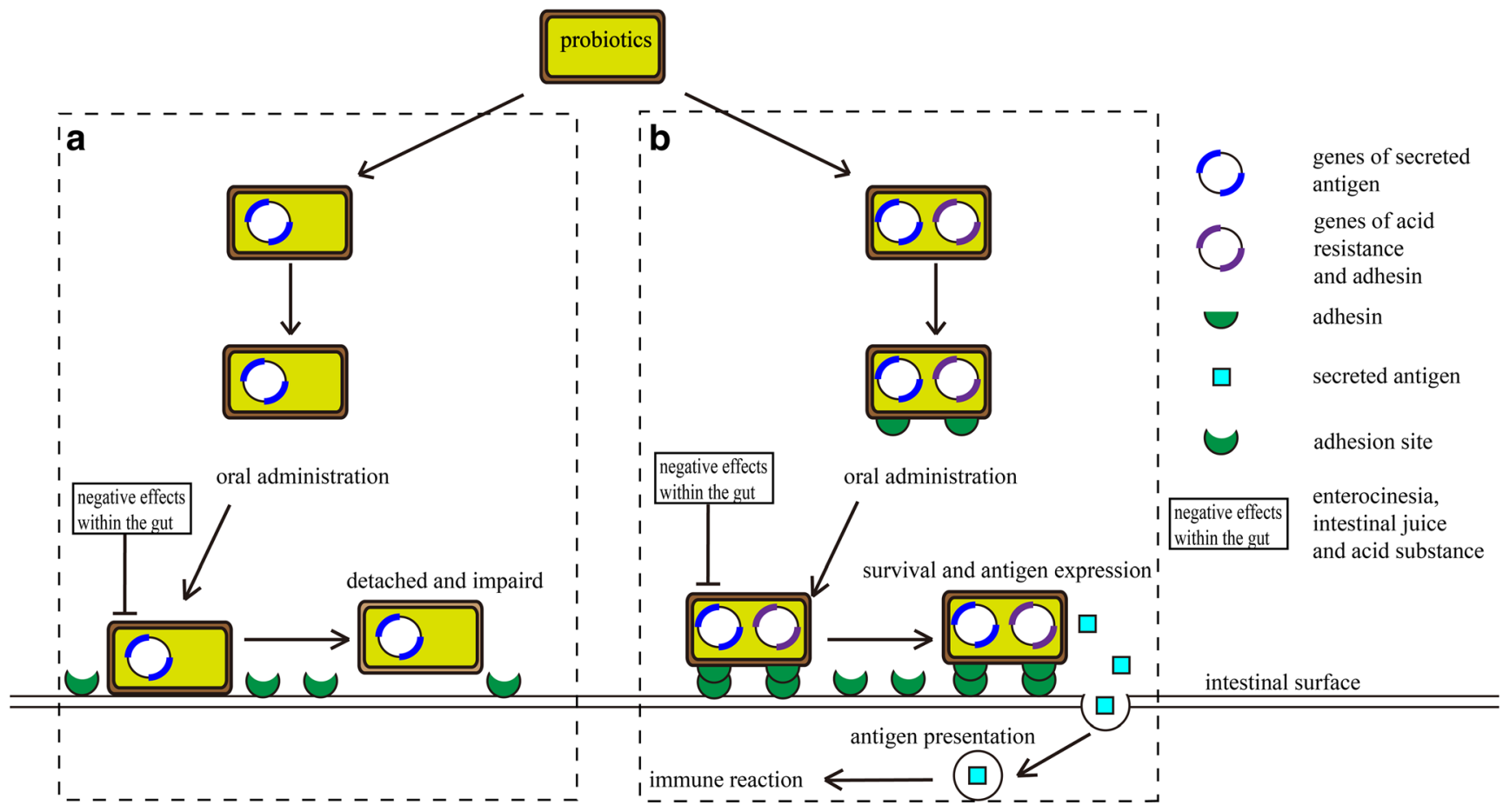

Fig. 3 Engineered probiotics for improving host colonization and enhancing immunoreactivity

It is essential for the oral vaccine based on probiotics to better survival within the gut considering the recombinant strain needs enough time for antigen expression and immune activation. (A) The recombinant probiotics expressing and secreting antigen has to resist adverse environment of enterocinesia as well as the washing of intestinal juice, and the

strains from product B show week adherence to human intestinal epithelial cells (Int-407), while the rest showed no adherence at all. We noticed our previous work (unpublished) on $\mathrm{EcN}$ showed that when EcN was orally administrated to piglets with the pre-treatment of neutralizing gastric acid for 6 days, there was rare $\mathrm{EcN}$ detected from feces in following days. Therefore, improvement of some probiotics' adherence to the gut is of necessity. Currently, there are three mainstream approaches to improving host adhesion and colonization of probiotics. Firstly, it has been widely studied that prebiotics and some metabolite of the host, like short-chain fatty or amino acids, play an important role in aiding in colonization of bacteria (Simpson and Campbell 2015). Therefore, it is reasonable to add those nutrients during oral vaccination as long as the detailed mechanism of auxo-action is clear enough to ensure specificity and stability. Alternatively, microspheres or microencapsulation have also been utilized and they can also facilitate the delivery of specific nutrition factors directly combining them with microspheres (Navarro et al. 2017). Researchers recently focus on the adherence factors of various probiotics. Since the property of adhesion is strain-specific, studies of key adherence factors (Duan et al. 2012; Duan et al. 2013; Yang et al. 2016) can not only provide us with insights into adherence but also guide us how to enhance it with efficiency. For instance, Gleinser et al. (2012) identified acid substance in the gut would impair their viability, like the increased permeability of cell wall. Therefore, the immunoreactivity of vaccines is weakened. (B) By contrast, when adding adhesins and acid-resistance genes to the antigen-secreting recombinant strain, theoretically it can successfully attach and colonize within the gut and therefore will have more opportunity to express antigen as well as exert other beneficial functions, which finally enhance vaccine's immunoreactivity.

the Bifidobacterium bifidum (B. bifidum)-specific lipoprotein BopA which functions as an adhesin and successfully expressed it in B. bifidum S17 and Bifidobacterium longum/ infantis (B. longum/infantis) E18 which showed enhanced adhesion to the intestinal epithelial cell (IEC) lines. Key adherence factors in Lactobacilli and the strain $\mathrm{EcN}$ have also been studied (Sanchez et al. 2008; Velez et al. 2007), but application of these important factors remains unclear since many features of adhesion are strain dependent. Except these mentioned above, it has also been discovered that combinational use of different probiotic strains showed significantly enhanced adhesion to intestinal mucus compared with individual strains (Collado et al. 2007a; unpublished data), which provides us with an innovative way of improving colonization.

\section{Enhance immunoreactivity}

Oral vaccines are crucial for the induction of mucosal immune response and secretion of SIgA. In this progress, dendritic cells (DCs) and microfold cells (M cells) play a vital role since antigen has to be firstly recognized by them and then presented to specific lymphocytes (Owen et al. 2013; Shima et al. 2014). However, DCs and M cells only mainly overlay mucosalassociated lymphoid tissue (MALT) like Peyer's patches and 
their quantity is pretty low in the intestinal tract (approximately $5 \%$ in humans and $10 \%$ in mice) (Azizi et al. 2010). However, previously developed oral vaccines seldom took the effective antigen recognition by DCs and M cells into consideration. Moreover, several studies demonstrated that not all probiotics can attach to Peyer's patches as efficiently as we previously thought. The study of Remer et al. (2009) showed that after oral vaccination of recombinant $\mathrm{EcN}$ expressing fimbrial adhesin K88, neither K88-specific T cell responses nor IgA titers against $\mathrm{K} 88$ in the feces were detected. It could be partly ascribed to the low level of immunoreactivity of the EcN, since stimulation of DC in vitro with purified K88 can induce the secretion of IL-6 which induces SIgA production. Furthermore, it has also been found that in the MALT, especially Peyer's patches where SIgA is mainly induced, only a small number of recombinant probiotic vectors can be detected (Shima et al. 2014). To address this problem, an innovative strategy of Peyer's patches-targeting vaccines which can both reduce the need of bulk antigen and improve immune efficacy has been proposed. Ma et al. (2018) have fused dendritic cell-targeting peptide (DCpep) and $\mathrm{M}$ cell-targeting peptide (Col) with the porcine epidemic diarrhea virus (PEDV) COE antigen expressed on the oral recombinant Lactobacillus vaccine. Its immune responses and protective efficacy in piglets were tested (Hou et al. 2018), and a stronger antigen-specific immune response was detected. The key point of this strategy is the selection of receptors that are specific to DCs or M cells and is effective for the uptake of antigens, as well as their ligands (Fig. $1)$. Reported receptors include $\beta 1$ integrins, pathogen recognition receptors (PRRs), specific carbohydrate residues, and the promising glycoprotein 2 (GP2) which can specifically bind to the type I pili (FimH) on bacterial outer membranes (Azizi et al. 2010). However, absolute specificity remains to be achieved because neighboring enterocytes can also express these receptors. Although at a lower level, these receptors may also have an adverse impact on the recognition of antigens, especially when ligands are perfectly specific. Therefore, the deeper understanding of M cells and DCs is still required.

\section{Bacterial spore delivery system-an innovative strategy}

Spores are dormant life forms of bacteria which are characterized by great robustness and can survive through harsh environmental conditions like high temperature and strong acid. Although previously considered as food contaminants which cannot colonize in animal GIT, recently, several studies have verified the germination of spore in the gut. Firstly, after oral inoculation of Bacillus subtilis (B. subtilis) spores into mice, the count of spores in feces is nearly 6 times larger than the initial inoculum (Hoa et al. 2001). Furthermore, Tam et al. (2006) proved the regeneration of spores with a molecular mark of TTFC antigen encoded by Clostridium tetani (C. tetani) tetC. They fused the $\mathrm{C}$. tetani tetC gene and B. subtilis rrnO gene, which is vegetatively expressed in B. subtilis, enabling the constitutive gene, including tetC expression, only in the vegetative cell. After oral administration of the recombinant $B$. subtilis spore into mice, high level of anti-TTFC IgG was detected. And it has also been found to own similar properties of microparticulate adjuvants (Barnes et al. 2007). Therefore, it is reasonable to consider bacterial spores as a potential oral vaccine candidate. Among probiotics, the genus Bacillus is mostly studied, especially the B. subtilis as the model of spore-forming bacteria. On the outer layer of its spores, there are abundant proteins, including $\operatorname{Cot} \mathrm{A}, \operatorname{Cot} \mathrm{B}, \operatorname{Cot} \mathrm{C}, \operatorname{CotD}$, and $\operatorname{Cot} \mathrm{G}$, that can facilitate the delivery of antigens (Duc and Cutting 2003). The standard antigen TTFC was chosen to test the efficiency of antigen expression and the immune reaction of spore vaccines. The chimeric protein, CotB-TTFC was expressed on the $B$. subtilis endospore (Duc et al. 2003b). After oral immunizations with the recombinant spore, a protective level of anti-TTFC IgG titer was observed and the final TTFC-specific SIgA titers were pretty higher than the controlled groups. Except the humoral immune response, a Th1 bias which produced following interaction of antigens with a CD4+ T cell has also been detected during the recombinant spore immunization.

Another way of spore displaying is the cytoplasmic delivery of antigens in vegetative cells. It has been proven that spores can proliferate in the gut as more spores than the orally administrated were detected in feces (Duc et al. 2003a). Moreover, investigators further demonstrated that spores can even survive and germinate after phagocytosis (Duc le et al. 2004). Advantages of this strategy include enhanced stress resistance of expressed antigen which is not directly exposed to the harsh environment in the gut and targeting antigen directly to the cytosol, which would contribute to a cellular immune response. When the protective antigen (PA) of B. anthracis was expressed in vegetative cells, a Th1 bias which induces secretion of IFN- $\gamma$ and IL-12, and increased titers of IgG2a antibodies were detected (Huang et al. 2008).

Our understanding of the gut flora and the mucosal immune system has been improved dramatically in recently years. Combined with the advanced genetically engineered technology, they promote the development of effective oral vaccines based on probiotics while requiring investigators to hold a systematic perspective during the processing, since any step of vaccine vector construction, if not considered carefully, might lead to dissatisfaction of vaccine development. And that is also of great significance when the extremely complicated environment of the gut is taken into consideration. Admittedly, it's only a theory; this review does not conclude each correlative detail but several essential ones. Nonetheless, we have made the first attempt to put them into a systematic way which could contribute to the advanced development of 
oral vaccines of probiotics, pointing out what ought to be deeply considered as well as what should not be neglected. We also recommend that the development of perfect oral vaccine vectors should be based on the complete understanding of essential issues, after which other new findings need to be explored. For example, recent studies on bacterial metabolism (Baumler and Sperandio 2016; Li et al. 2018; Ren et al. 2018) and quorum sensing (QS) (Shiner et al. 2005) have respectively revealed that the metabolite and some secretory products of bacteria play an extensive role in the physiology of both pathogens and the host. These innovative findings might significantly help us to evaluate the security of probiotic vectors as well as to optimize their function.

To further develop the probiotic vectors, some issues still need to be tackled. For instance, the time that vectors exist in the gut and the consequence of long-term existence ought to be carefully considered, since the colonization of the recombinant probiotics would be greatly improved in the future. Technologies of synthetic biology are looking forward to being applicable to this issue (Pedrolli et al. 2018). Considering current studies of carriers based on attenuated pathogens are still more advanced than probiotic strains (da Silva et al. 2014). Therefore, the development of more potent vectors of probiotics should pay more attention to the unique features discovered in probiotics and the elaborate scheme of how to exploit them, instead of completely following the existent strategies on attenuated pathogens.

Funding information This study was supported by Grant No. 2017YFD0500105, 2016YFD0500905 from the National Key Research and Development Program of China, grant No.AA18118050 from the Department of Science and Technology in Guangxi Autonomous Region, grants from the Chinese National Science Foundation Grant (No. 31672579, 31873010, 31800121, 30571374, 30771603, 31072136,31270171 ), by international collaboration program of the Science and Technology Department of Yangzhou (Grant No. YZ2018154), a project founded by the Priority Academic Program of Development Jiangsu High Education Institution.

\section{Compliance with ethical standards}

Conflicts of interest The authors declare that they have no competing interests.

Ethical approval This article does not contain any studies with human participants or animals performed by any of the authors.

\section{References}

Abdullah Al M, Sugimoto S, Higashi C, Matsumoto S, Sonomoto K (2010) Improvement of multiple-stress tolerance and lactic acid production in Lactococcus lactis NZ9000 under conditions of thermal stress by heterologous expression of Escherichia coli DnaK. Appl Environ Microbiol 76(13):4277-4285. https://doi.org/10.1128/ AEM.02878-09
Akhverdyan VZ, Gak ER, Tokmakova IL, Stoynova NV, Yomantas YA, Mashko SV (2011) Application of the bacteriophage Mu-driven system for the integration/amplification of target genes in the chromosomes of engineered Gram-negative bacteria-mini review. Appl Microbiol Biotechnol 91(4):857-871. https://doi.org/10.1007/ s00253-011-3416-y

Amar J, Chabo C, Waget A, Klopp P, Vachoux C, Bermudez-Humaran LG, Smirnova N, Berge M, Sulpice T, Lahtinen S, Ouwehand A, Langella P, Rautonen N, Sansonetti PJ, Burcelin R (2011) Intestinal mucosal adherence and translocation of commensal bacteria at the early onset of type 2 diabetes: molecular mechanisms and probiotic treatment. EMBO Mol Med 3(9):559-572. https://doi.org/10.1002/ emmm.201100159

Anbazhagan K, Sasikumar P, Gomathi S, Priya HP, Selvam GS (2013) In vitro degradation of oxalate by recombinant Lactobacillus plantarum expressing heterologous oxalate decarboxylase. J Appl Mircobiol 115(3):880-887. https://doi.org/10.1111/jam.12269

Azizi A, Kumar A, Diaz-Mitoma F, Mestecky J (2010) Enhancing oral vaccine potency by targeting intestinal M cells. PLoS Pathog 6(11): e1001147. https://doi.org/10.1371/journal.ppat.1001147

Barnes AG, Cerovic V, Hobson PS, Klavinskis LS (2007) Bacillus subtilis spores: a novel microparticle adjuvant which can instruct a balanced Th1 and Th2 immune response to specific antigen. Eur J Immunol 37(6):1538-1547. https://doi.org/10.1002/eji.200636875

Baumler AJ, Sperandio V (2016) Interactions between the microbiota and pathogenic bacteria in the gut. Nature 535(7610):85-93. https://doi. org/10.1038/nature 18849

Bezkorovainy A (2001) Probiotics: determinants of survival and growth in the gut. Am J Clin Nutr 73(2):399S-405S

Bohmer N, Lutzwahl S, Fischer L (2012) Recombinant production of hyperthermostable CelB from Pyrococcus furiosus in Lactobacillus sp. Appl Microbiol Biotechnol 96(4):903-912. https://doi.org/10.1007/s00253-012-4212-z

Bonacina J, Suarez N, Hormigo R, Fadda S, Lechner M, Saavedra L (2017) A genomic view of food-related and probiotic Enterococcus strains. DNA Res 24(1):11-24. https://doi.org/10. 1093/dnares/dsw043

Bryant JA, Sellars LE, Busby SJW, Lee DJ (2014) Chromosome position effects on gene expression in Escherichia coli K-12. Nucleic Acids Res 42(18):11383-11392. https://doi.org/10.1093/nar/gku828

Buddenborg C, Daudel D, Liebrecht S, Greune L, Humberg V, Schmidt MA (2008) Development of a tripartite vector system for live oral immunization using a gram-negative probiotic carrier. Int J Med Microbiol 298(1-2):105-114. https://doi.org/10.1016/j.ijmm.2007. 08.008

Caggianiello G, Kleerebezem M, Spano G (2016) Exopolysaccharides produced by lactic acid bacteria: from health-promoting benefits to stress tolerance mechanisms. Appl Microbiol Biotechnol 100(9): 3877-3886. https://doi.org/10.1007/s00253-016-7471-2

Carvalho AL, Cardoso FS, Bohn A, Neves AR, Santos H (2011) Engineering trehalose synthesis in Lactococcus lactis for improved stress tolerance. Appl Environ Microbiol 77(12):4189-4199. https:// doi.org/10.1128/AEM.02922-10

Chaconas G, Gloor G, Miller JL (1985) Amplification and purification of the bacteriophage $\mathrm{Mu}$ encoded B transposition protein. J Biol Chem 260(5):2662-2669

Chaves ACSD, Fernandez M, Lerayer ALS, Mierau I, Kleerebezem M, Hugenholtz J (2002) Metabolic engineering of acetaldehyde production by Streptococcus thermophilus. Appl Environ Microbiol 68(11):5656-5662. https://doi.org/10.1128/aem.68.11.5656-5662. 2002

Collado MC, Meriluoto J, Salminen S (2007a) Development of new probiotics by strain combinations: is it possible to improve the adhesion to intestinal mucus? J Dairy Sci 90(6):2710-2716. https:// doi.org/10.3168/jds.2006-456 
Collado MC, Meriluoto J, Salminen S (2007b) In vitro analysis of probiotic strain combinations to inhibit pathogen adhesion to human intestinal mucus. Food Res Int 40(5):629-636. https://doi.org/10. 1016/j.foodres.2006.11.007

Collado MC, Sanz Y (2007) Induction of acid resistance in Bifidobacterium: a mechanism for improving desirable traits of potentially probiotic strains. J Appl Microbiol 103(4):1147-1157. https://doi.org/10.1111/j.1365-2672.2007.03342.x

Cong L, Ran FA, Cox DM, Lin S, Barretto RPJ, Habib N, Hsu P, Wu X, Jiang W, Marraffini LA (2013) Multiplex genome engineering using CRISPR/Cas systems. Science 339(6121):819-823. https://doi.org/ 10.1126/science. 1231143

Córdoba Park Hotel A (2001) Health and nutritional properties of probiotics in food including powder milk with live lactic acid bacteria - Joint FAO/WHO Expert Consultation, vol 2014,

Czaplewski L, Bax R, Clokie M, Dawson M, Fairhead H, Fischetti VA, Foster S, Gilmore BF, Hancock REW, Harper D, Henderson IR, Hilpert K, Jones BV, Kadioglu A, Knowles D, Olafsdottir S, Payne D, Projan S, Shaunak S, Silverman J, Thomas CM, Trust TJ, Warn P, Rex JH (2016) Alternatives to antibiotics-a pipeline portfolio review. Lancet Infect Dis 16(2):239-251. https://doi.org/ 10.1016/s1473-3099(15)00466-1

da Silva AJ, Zangirolami TC, Novo-Mansur MTM, Giordano RC, Martins EAL (2014) Live bacterial vaccine vectors: an overview. Braz J Microbiol 45(4):1117-1129. https://doi.org/10.1590/s151783822014000400001

Ding C, Ma J, Dong Q, Liu Q (2018) Live bacterial vaccine vector and delivery strategies of heterologous antigen: a review. Immunol Lett 197:70-77. https://doi.org/10.1016/j.imlet.2018.03.006

Dodoo CC, Wang J, Basit AW, Stapleton P, Gaisford S (2017) Targeted delivery of probiotics to enhance gastrointestinal stability and intestinal colonisation. Int J Pharm 530(1-2):224-229. https://doi.org/10. 1016/j.jpharm.2017.07.068

Duan QD, Zhou MX, Zhu XF, Bao WB, Wu SL, Ruan XS, Zhang WP, Yang Y, Zhu J, Zhu GQ (2012) The flagella of F18ab Escherichia coli is a virulence factor that contributes to infection in a IPEC-J2 cell model in vitro. Vet Microbiol 160(1-2):132-140. https://doi. org/10.1016/j.vetmic.2012.05.015

Duan QD, Zhou MX, Liang H, Zhu XF, Guo ZY, Li YC, Hardwidge PR, Zhu GQ (2013) Contribution of flagellin subunit FliC to piglet epithelial cells invasion by F18ab E. coli. Vet Microbiol 166(1-2): 220-224. https://doi.org/10.1016/j.vetmic.2013.04.030

Duc le H, Hong HA, Uyen NQ, Cutting SM (2004) Intracellular fate and immunogenicity of B. subtilis spores. Vaccine 22(15-16):18731885. https://doi.org/10.1016/j.vaccine.2003.11.021

Duc LH, Cutting SM (2003) Bacterial spores as heat stable vaccine vehicles. Expert Opin Biol Th 3(8):1263-1270. https://doi.org/10. 1517/14712598.3.8.1263

Duc LH, Hong HA, Cutting SM (2003a) Germination of the spore in the gastrointestinal tract provides a novel route for heterologous antigen delivery. Vaccine 21(27-30):4215-4224. https://doi.org/10.1016/ s0264-410x(03)00492-4

Duc LH, Hong HA, Fairweather N, Ricca E, Cutting SM (2003b) Bacterial spores as vaccine vehicles. Infect Immun 71(5):2810 2818. https://doi.org/10.1128/iai.71.5.2810-2818.2003

Wang HH, Isaacs FJ, Carr PA, Sun ZZ, Xu G, Forest CR, Church GM (2009) Programming cells by multiplex genome engineering and accelerated evolution. Nature 460(7257):894-U133. https://doi. org/10.1038/nature08187

Fang H, Elina T, Heikki A, Seppo S (2000) Modulation of humoral immune response through probiotic intake. FEMS Immunol Med Microbiol 29(1):47-52. https://doi.org/10.1016/s0928-8244(00) 00187-5

Floch MH, Walker WA, Madsen K, Sanders ME, Macfarlane GT, Flint HJ, Dieleman LA, Ringel Y, Guandalini S, Kelly CP, Brandt LJ (2011) Recommendations for probiotic use-2011 update. J Clin
Gastroenterol 45:S168-S171. https://doi.org/10.1097/MCG. 0b013e318230928b

Fredriksen L, Kleiveland CR, Hult LTO, Lea T, Nygaard CS, Eijsink VGH, Mathiesen G (2012) Surface display of N-terminally anchored invasin by Lactobacillus plantarum activates NF- $\mathrm{KB}$ in monocytes. Appl Environ Microbiol 78(16):5864-5871. https:// doi.org/10.1128/AEM.01227-12

Gahan ME, Webster DE, Wesselingh SL, Strugnell RA (2007) Impact of plasmid stability on oral DNA delivery by Salmonella enterica serovar typhimurium. Vaccine 25(8):1476-1483. https://doi.org/10. 1016/j.vaccine.2006.10.042

Gentschev I, Dietrich G, Goebel W (2002) The E. coli alpha-hemolysin secretion system and its use in vaccine development. Trends Microbiol 10(1):39-45. https://doi.org/10.1016/s0966-842x(01) 02259-4

Gleinser M, Grimm V, Zhurina D, Yuan J, Riedel CU (2012) Improved adhesive properties of recombinant bifidobacteria expressing the Bifidobacterium bifidum-specific lipoprotein BopA. Microb Cell Factories 11:14. https://doi.org/10.1186/1475-2859-11-80

Goldhaber-Gordon I, Williams TL, Baker TA (2002) DNA recognition sites activate MuA transposase to perform transposition of non-Mu DNA. J Biol Chem 277(10):7694-7702. https://doi.org/10.1074/ jbc.M110341200

Gomez NC, Ramiro JMP, Quecan BXV, de Melo Franco BDG (2016) Use of potential probiotic lactic acid Bacteria (LAB) biofilms for the control of Listeria monocytogenes, Salmonella Typhimurium, and Escherichia coli O157:H7 biofilms formation. Front Microbiol 7: 15. https://doi.org/10.3389/fmicb.2016.00863

Grimm V, Westermann C, Riedel CU (2014) Bifidobacteria-host interactions - an update on colonisation factors. Biomed Res Int 2014:960826-960826. https://doi.org/10.1155/2014/960826

Gu Q, Song D, Zhu M (2009) Oral vaccination of mice against Helicobacter pylori with recombinant Lactococcus lactis expressing urease subunit B. FEMS Immunol Med Microbiol 56(3):197-203. https://doi.org/10.1111/j.1574-695X.2009.00566.x

Haldimann A, Wanner BL (2001) Conditional-replication, integration, excision, and retrieval plasmid-host systems for gene structurefunction studies of bacteria. J Bacteriol 183(21):6384-6393. https://doi.org/10.1128/jb.183.21.6384-6393.2001

Herich R, Levkut M (2002) Lactic acid bacteria, probiotics and immune system. Vet Med-Czech 47(6):169-180. https://doi.org/10.17221/ 5821-vetmed

Hoa TT, Duc LH, Isticato R, Baccigalupi L, Ricca E, Van PH, Cutting SM (2001) Fate and dissemination of Bacillus subtilis spores in a murine model. Appl Environ Microbiol 67(9):3819-3823. https://doi.org/ 10.1128/aem.67.9.3819-3823.2001

Holmgren J, Czerkinsky C (2005) Mucosal immunity and vaccines. Nat Med 11:S45-S53. https://doi.org/10.1038/nm1213

Hossain MI, Sadekuzzaman M, Ha SD (2017) Probiotics as potential alternative biocontrol agents in the agriculture and food industries: a review. Food Res Int 100:63-73. https://doi.org/10.1016/j.foodres. 2017.07.077

Hou X, Jiang X, Jiang Y, Tang L, Xu Y, Qiao X, Min L, Wen C, Ma G, Li $Y$ (2018) Oral immunization against PEDV with recombinant Lactobacillus casei expressing dendritic cell-targeting peptide fusing COE protein of PEDV in piglets. Viruses 10(3). https://doi.org/ 10.3390/v10030106

Huang JM, La Ragione RM, Cooley WA, Todryk S, Cutting SM (2008) Cytoplasmic delivery of antigens, by Bacillus subtilis enhances Th1 responses. Vaccine 26(48):6043-6052. https://doi.org/10.1016/j. vaccine.2008.09.024

Isolauri E, Majamaa H, Arvola T, Rantala I, Virtanen E, Arvilommi H (1993) Lactobacillus casei strain GG reverses increased intestinal permeability induced by cow milk in suckling rats. Gastroenterology 105(6):1643-1650. https://doi.org/10.1016/00165085(93)91059-q 
Iwaki M, Okahashi N, Takahashi I, Kanamoto T, Sugitakonishi Y, Aibara K, Koga T (1990) Oral immunization with recombinant Streptococcus lactis carrying the Streptococcus mutans surface protein antigen gene. Infect Immun 58(9):2929-2934

Jiang Y, Chen B, Duan C, Sun B, Yang J, Yang S (2015) Multigene editing in the Escherichia coli genome via the CRISPR-Cas9 system. Appl Environ Microbiol 81(7):2506-2514. https://doi.org/10. 1128/AEM.04023-14

Kanchiswamy CN, Maffei M, Malnoy M, Velasco R, Kim JS (2016) Fine-tuning next-generation genome editing tools. Trends Biotechnol 34(7):562-574. https://doi.org/10.1016/j.tibtech.2016. 03.007

Kanjee U, Houry WA (2013) Mechanisms of acid resistance in Escherichia coli. In: Gottesman S (ed) Annu Rev Microbiol, vol 67. Annual Reviews, Palo Alto, pp 65-81

Kanmani P, Kumar RS, Yuvaraj N, Paari KA, Pattukumar V, Arul V (2013) Probiotics and its functionally valuable products - a review. Crit Rev Food Sci 53(6):641-658. https://doi.org/10.1080/ 10408398.2011.553752

Karlskas IL, Maudal K, Axelsson L, Rud I, Eijsink VG, Mathiesen G (2014) Heterologous protein secretion in Lactobacilli with modified pSIP vectors. PLoS One 9(3):e91125. https://doi.org/10.1371/ journal.pone.0091125

Kaufmann SHE, Hess J (1999) Impact of intracellular location of and antigen display by intracellular bacteria: implications for vaccine development. Immunol Lett 65:81-84. https://doi.org/10.1016/ S0165-2478(98)00128-X

Kuda T, Kawahara M, Nemoto M, Takahashi H, Kimura B (2014) In vitro antioxidant and anti-inflammation properties of lactic acid bacteria isolated from fish intestines and fermented fish from the Sanriku Satoumi region in Japan. Food Res Int 64:248-255. https://doi.org/ 10.1016/j.foodres.2014.06.028

Kumar M, Yadav AK, Verma V, Singh B, Mal G, Nagpal R, Hemalatha R (2016) Bioengineered probiotics as a new hope for health and diseases: an overview of potential and prospects. Future Microbiol 11(4):585-600. https://doi.org/10.2217/fmb.16.4

Wu XS, Xin L, Yin WX, Shang XY, Lu L, Watt RM, Cheah KSE, Huang JD, Liu DP, Liang CC (2005) Increased efficiency of oligonucleotide-mediated gene repair through slowing replication fork progression. Proc Natl Acad Sci U S A 102(7):2508-2513. https://doi.org/10.1073/pnas.0406991102

Lee SF, Halperin SA, Wang H, MacArthur A (2002) Oral colonization and immune responses to Streptococcus gordonii expressing a pertussis toxin S1 fragment in mice. FEMS Microbiol Lett 208(2):175178. https://doi.org/10.1016/s0378-1097(02)00457-3

Li ZD, Quan GM, Jiang XY, Yang Y, Ding XY, Zhang D, Wang XQ, Hardwidge PR, Ren WK, Zhu GQ (2018) Effects of metabolites derived from gut microbiota and hosts on pathogens. Front Cell Infect Microbiol 8:12. https://doi.org/10.3389/fcimb.2018.00314

Lin WH, Hwang CF, Chen LW, Tsen HY (2006) Viable counts, characteristic evaluation for commercial lactic acid bacteria products. Food Microbiol 23(1):74-81. https://doi.org/10.1016/j.fm.2005.01.013

Ma S, Wang L, Huang X, Wang X, Chen S, Shi W, Qiao X, Jiang Y, Tang L, Xu Y, Li Y (2018) Oral recombinant Lactobacillus vaccine targeting the intestinal microfold cells and dendritic cells for delivering the core neutralizing epitope of porcine epidemic diarrhea virus. Microb Cell Factories 17(1):20. https://doi.org/10.1186/ s12934-018-0861-7

Marelli B, Perez AR, Banchio C, de Mendoza D, Magni C (2011) Oral immunization with live Lactococcus lactis expressing rotavirus VP8 subunit induces specific immune response in mice. J Virol Methods 175(1):28-37. https://doi.org/10.1016/j.jviromet.2011.04.011

Medina E, Guzman CA (2001) Use of live bacterial vaccine vectors for antigen delivery: potential and limitations. Vaccine 19:1573-1580. https://doi.org/10.1016/S0264-410X(00)00354-6
Murphy K (2016) $\lambda$ recombination and Recombineering. EcoSal plus 7(1). https://doi.org/10.1128/ecosalplus.ESP-0011-2015

Navarro JB, Mashburn-Warren L, Bakaletz LO, Bailey MT, Goodman SD (2017) Enhanced probiotic potential of Lactobacillus reuteri when delivered as a biofilm on Dextranomer microspheres that contain beneficial cargo. Front Microbiol 8:489. https://doi.org/10. 3389/fmicb.2017.00489

Nouaille S, Bermudez-Humaran LG, Adel-Patient K, Commissaire J, Gruss A, Wal GM, Azevedo V, Langella P, Chatel JM (2005) Improvement of bovine beta-lactoglobulin production and secretion by Lactococcus lactis. Braz J Med Biol Res 38(3):353-359. https:// doi.org/10.1590/s0100-879x2005000300005

Ou BM, Garcia C, Wang YJ, Zhang WP, Zhu GQ (2018) Techniques for chromosomal integration and expression optimization in Escherichia coli. Biotechnol Bioeng 115(10):2467-2478. https:// doi.org/10.1002/bit.26790

Ou B, Yang Y, Tham WL, Chen L, Guo J, Zhu G (2016) Genetic engineering of probiotic Escherichia coli Nissle 1917 for clinical application. Appl Microbiol Biotechnol 100(20):8693-8699. https://doi. org/10.1007/s00253-016-7829-5

Owen JL, Sahay B, Mohamadzadeh M (2013) New generation of oral mucosal vaccines targeting dendritic cells. Curr Opin Chem Biol 17(6):918-924. https://doi.org/10.1016/j.cbpa.2013.06.013

Paccez JD, Nguyen HD, Luiz WB, Ferreira RC, Sbrogio-Almeida ME, Schuman W, Ferreira LC (2007) Evaluation of different promoter sequences and antigen sorting signals on the immunogenicity of Bacillus subtilis vaccine vehicles. Vaccine 25(24):4671-4680. https://doi.org/10.1016/j.vaccine.2007.04.021

Pedrolli DB, Ribeiro NV, Squizato PN, de Jesus VN, Cozetto DA, Team AQAUai (2018) Engineering microbial living therapeutics: the synthetic biology toolbox. Trends Biotechnol 37(1):100-115. https:// doi.org/10.1016/j.tibtech.2018.09.005

Pinto-Sanchez MI, Hall GB, Ghajar K, Nardelli A, Bolino C, Lau JT, Martin FP, Cominetti O, Welsh C, Rieder A, Traynor J, Gregory C, De Palma G, Pigrau M, Ford AC, Macri J, Berger B, Bergonzelli G, Surette MG, Collins SM, Moayyedi P, Bercik P (2017) Probiotic Bifidobacterium longum NCC3001 reduces depression scores and alters brain activity: a pilot study in patients with irritable bowel syndrome. Gastroenterology 153(2):448-+ doi:https://doi.org/10. 1053/j.gastro.2017.05.003

Radford KJ, Higgins DE, Pasquini S, Cheadle EJ, Carta L, Jackson AM, Lemoine NR, Vassaux G (2002) A recombinant $E$. coli vaccine to promote MHC class I-dependent antigen presentation: application to cancer immunotherapy. Gene Ther 9(21):1455-1463. https://doi. org/10.1038/sj.gt.3301812

Rajput IR, Li WF (2012) Potential role of probiotics in mechanism of intestinal immunity. Pak Vet J 32(3):303-308

Remer KA, Bartrow M, Roeger B, Moll H, Sonnenborn U, Oelschlaeger TA (2009) Split immune response after oral vaccination of mice with recombinant Escherichia coli Nissle 1917 expressing fimbrial adhesin K88. Int J Med Microbiol 299(7):467-478. https://doi.org/ 10.1016/j.jimm.2009.03.003

Ren W, Rajendran R, Zhao Y, Tan B, Wu G, Bazer FW, Zhu G, Peng Y, Huang X, Deng J, Yin Y (2018) Amino acids as mediators of metabolic cross talk between host and pathogen. Front Immunol 9:13. https://doi.org/10.3389/fimmu.2018.00319

Rombout J, Abelli L, Picchietti S, Scapigliati G, Kiron V (2011) Teleost intestinal immunology. Fish Shellfish Immun 31(5):616-626. https://doi.org/10.1016/j.fsi.2010.09.001

Ribeiro LA, Azevedo V, Le Loir Y, Oliveira SC, Dieye Y, Piard JC, Gruss A, Langella P (2002) Production and targeting of the Brucella abortus antigen L7/L12 in Lactococcus lactis: a first step towards food-grade live vaccines against brucellosis. Appl Environ Microbiol 68(2):910-916. https://doi.org/10.1128/aem.68.2.910916.2002 
Russell-Jones GJ (2000) Oral vaccine delivery. J Control Release 65:49 54. https://doi.org/10.1016/S0168-3659(99)00231-X

Sanchez B, Bressollier P, Urdaci MC (2008) Exported proteins in probiotic bacteria: adhesion to intestinal surfaces, host immunomodulation and molecular cross-talking with the host. FEMS Immunol Med Microbiol 54(1):1-17. https://doi.org/10. 1111/j.1574-695X.2008.00454.x

Schneewind O, Missiakas DM (2012) Protein secretion and surface display in Gram-positive bacteria. Philos Trans R Soc Lond Ser B Biol Sci 367(1592):1123-1139. https://doi.org/10.1098/rstb.2011.0210

Seegers J (2002) Lactobacilli as live vaccine delivery vectors: progress and prospects. Trends Biotechnol 20(12):508-515. https://doi.org/ 10.1016/s0167-7799(02)02075-9

Shima H, Watanabe T, Fukuda S, Fukuoka S, Ohara O, Ohno H (2014) A novel mucosal vaccine targeting Peyer's patch $\mathrm{M}$ cells induces protective antigen-specific IgA responses. Int Immunol 26(11):619 625. https://doi.org/10.1093/intimm/dxu061

Shiner EK, Rumbaugh KP, Williams SC (2005) Inter-kingdom signaling: deciphering the language of acyl homoserine lactones. FEMS Microbiol Rev 29(5):935-947. https://doi.org/10.1016/j.femsre. 2005.03.001

Siegel SD, Reardon ME, Tonthat H (2016) Anchoring of LPXTG-like proteins to the Gram-positive cell wall envelope. Curr Top Microbiol vol 404. Springer-Verlag Berlin, Berlin, pp 159-175 doi: https://doi.org/10.1007/82_2016_8

Simpson HL, Campbell BJ (2015) Review article: dietary fibremicrobiota interactions. Aliment Pharmacol Ther 42(2):158-179. https://doi.org/10.1111/apt.13248

Sonnenborn U, Schulze J (2009) The non-pathogenic Escherichia coli strain Nissle 1917 - features of a versatile probiotic. Microb Ecol Health Dis 21(3-4):122-158. https://doi.org/10.3109/ 08910600903444267

Stout E, Klaenhammer T, Barrangou R (2017) CRISPR-Cas technologies and applications in food bacteria. In: Doyle MP, Klaenhammer TR (eds) Annu Rev Food Sci T, vol 8. Annual Reviews, Palo Alto, pp 413-437

Tam NK, Uyen NQ, Hong HA, Duc le H, Hoa TT, Serra CR, Henriques AO, Cutting SM (2006) The intestinal life cycle of Bacillus subtilis and close relatives. J Bacteriol 188(7):2692-2700. https://doi.org/ 10.1128/JB.188.7.2692-2700.2006

Taylor AL, Hale J, Wiltschut J, Lehmann H, Dunstan JA, Prescott SL (2006) Effects of probiotic supplementation for the first 6 months of life on allergen- and vaccine-specific immune responses. Clin Exp Allergy 36(10):1227-1235. https://doi.org/10.1111/j.1365-2222. 2006.02553.x

Van Pijkeren JP, Barrangou R (2017) Genome editing of food-grade Lactobacilli to develop therapeutic probiotics. Microbiol Spectr 5(5):16. https://doi.org/10.1128/microbiolspec.BAD-0013-2016

Velez MP, De Keersmaecker SCJ, Vanderleyden J (2007) Adherence factors of Lactobacillus in the human gastrointestinal tract. FEMS Microbiol Lett 276(2):140-148. https://doi.org/10.1111/j.15746968.2007.00908.x

Villena J, Medina MF, Racedo S, Alvarez S (2010) Resistance of young mice to pneumococcal infection can be improved by oral vaccination with recombinant Lactococcus lactis. J Micrbiol Immunol 43(1):1-10. https://doi.org/10.1016/S1684-1182(10)60001-1
Vitini E, Alvarez S, Medina M, Medici M, De Budeguer MV, Perdigon G (2000) Gut mucosal immunostimulation by lactic acid bacteria. Biocell 24(3):223-232

Vogt CM, Schraner EM, Aguilar C, Eichwald C (2016) Heterologous expression of antigenic peptides in Bacillus subtilis biofilms. Microb Cell Factories 15(1):137. https://doi.org/10.1186/s12934016-0532-5

Wang C, Cui Y, Qu X (2018) Mechanisms and improvement of acid resistance in lactic acid bacteria. Arch Microbiol 200(2):195-201. https://doi.org/10.1007/s00203-017-1446-2

Wang HH, Church GM (2011) Multiplexed genome engineering and genotyping methods applications for synthetic biology and metabolic engineering. Methods Enzymol 498:409-426. https://doi.org/10. 1016/B978-0-12-385120-8.00018-8

Wang L, Yang Y, Cai B, Cao P, Yang M, Chen Y (2014a) Coexpression and secretion of endoglucanase and phytase genes in Lactobacillus reuteri. Int J Mol Sci 15(7):12842-12860. https://doi.org/10.3390/ ijms 150712842

Wang X, Chen W, Tian Y, Mao Q, Lv X, Shang M, Li X, Yu X, Huang Y (2014b) Surface display of Clonorchis sinensis enolase on Bacillus subtilis spores potentializes an oral vaccine candidate. Vaccine 32(12):1338-1345. https://doi.org/10.1016/j.vaccine.2014.01.039

Warming S, Costantino N, Court DL, Jenkins NA, Copeland NG (2005) Simple and highly efficient BAC recombineering using gaIK selection. Nucleic Acids Res 33(4):12. https://doi.org/10.1093/nar/ gni035

Wassenaar TM (2016) Insights from 100 years of research with probiotic E. coli. Eur J Microbiol Immunol (Bp) 6(3):147-161. https://doi. org/10.1556/1886.2016.00029

Wei XX, Shi ZY, Li ZJ, Cai L, Wu Q, Chen GQ (2010) A mini-Mu transposon-based method for multiple DNA fragment integration into bacterial genomes. Appl Microbiol Biotechnol 87(4):15331541. https://doi.org/10.1007/s00253-010-2674-4

Wu CD, Zhang J, Chen W, Wang M, Du GC, Chen J (2012) A combined physiological and proteomic approach to reveal lactic-acid-induced alterations in Lactobacillus casei Zhang and its mutant with enhanced lactic acid tolerance. Appl Microbiol Biotechnol 93(2): 707-722. https://doi.org/10.1007/s00253-011-3757-6

Wyszynska A, Kobierecka P, Bardowski J, Jagusztyn-Krynicka EK (2015) Lactic acid bacteria-20 years exploring their potential as live vectors for mucosal vaccination. Appl Microbiol Biotechnol 99(7): 2967-2977. https://doi.org/10.1007/s00253-015-6498-0

Yang Y, Yang Y, Ou BM, Xia PP, Zhou MX, Li L, Zhu GQ (2016) The flagellin hypervariable region is a potential flagella display domain in probiotic Escherichia coli strain Nissle 1917. Arch Microbiol 198(7):603-610. https://doi.org/10.1007/s00203-016-1219-3

Zhang J, Wu CD, Du GC, Chen J (2012) Enhanced acid tolerance in Lactobacillus casei by adaptive evolution and compared stress response during acid stress. Biotechnol Bioprocess Eng 17(2):283289. https://doi.org/10.1007/s12257-011-0346-6

Publisher's note Springer Nature remains neutral with regard to jurisdictional claims in published maps and institutional affiliations. 